\title{
Corrosion Behavior of Plasma Nitrided and Nitrocarburised Supermartensitic Stainless Steel
}

\author{
Frederico Augusto Pires Fernandes $*^{\circledR}$, Carlos Alberto Picone ${ }^{b}$, George Edward Totten ${ }^{c}$
}

\author{
Luiz, Carlos Castelettid
}

\author{
${ }^{a}$ Centro de Engenharia, Modelagem e Ciências Sociais Aplicadas, Universidade Federal do ABC, \\ Alameda da Universidade, s/n, 09606-070, São Bernardo do Campo, SP, Brasil \\ ${ }^{b}$ Faculdade de Engenharia de Ilha Solteira, Universidade Estadual Paulista, Av. Brasil Centro, n. 56, \\ 15385-000, Ilha Solteira, SP, Brasil \\ ${ }^{c}$ Department of Mechanical and Materials Engineering, Portland State University, Portland, OR, USA \\ ${ }^{d}$ Departamento de Engenharia de Materiais, Escola de Engenharia de São Carlos, Universidade de São \\ Paulo, Av. João Dagnone, n. 1100, 13563-120, São Carlos, SP, Brasil
}

Received: October 24, 2016; Revised: December 05, 2017; Accepted: February 07, 2018

\begin{abstract}
Supermartensitic stainles steels (SMSS's) are a new generation of martensitic steels that have been increasingly used in oil and gas applications due to their adequate corrosion resistance and mechanical properties. In the present study, SMSS specimens (UNS S41425) were solution heat treated and air cooled followed by plasma nitriding and nitrocarburising at 400,450 and $500^{\circ} \mathrm{C}$ for $5 \mathrm{~h}$. The produced layers were characterized by optical microscopy, microhardness testing, X-ray diffraction and corrosion testing in $\mathrm{NaCl} 3.5 \%$ solution. Surface alloying with nitrogen or both nitrogen and carbon results in increased surface hardness and homogeneous layers in which layer thickness increases with temperature. However, plasma nitriding yields a slightly thicker case than nitrocarburising. X-ray diffraction indicates very broad and overlapped peaks for the treatments conducted at $400^{\circ} \mathrm{C}$. Increasing treatment temperature appears to result in the formation of chromium nitrides and iron nitrides and carbides, depending on the treatment. It was also found that treatment temperature drastically affects the corrosion response of the steel. The untreated steel presented a pitting potential close to $250 \mathrm{mV}$. Plasma nitriding at $400^{\circ} \mathrm{C}$ was the only condition in which significant improvement of corrosion is observed. For plasma nitriding and nitrocarburising at 450 and $500^{\circ} \mathrm{C}$, some pitting was detected.
\end{abstract}

Keywords: Supermartensitic stainless steels, Plasma nitriding, Plasma nitrocarburising, Corrosion.

\section{Introduction}

The so called supermartensitic stainless steels (SMSS's) are a new generation of the classic $13 \% \mathrm{Cr}$ martensitic steels with additional alloying elements. Its chemical composition is based on the classical martensitic stainless steels (AISI 410 and 420) with further additions of nickel and molybdenum in suitable amounts and, reduced carbon content ${ }^{1,2}$. This class of steel was developed in the late 1990's mainly for onshore and offshore pipeline applications ${ }^{1,2}$. Such steels became attractive due to its relatively low price, high strength, adequate corrosion resistance and weldability ${ }^{1,3,4}$.

The typical heat treated microstructure of the SMSS's is characterized by tempered martensite and retained austenite at room temperature. To date the SMSS's have found application as alternative materials for multipurpose use in the oil and gas industry as a substitute of the super-duplex $\operatorname{grades}^{1,5}$. Several papers in the literature are dedicated to the metallurgy and heat treatment of the SMSS's ${ }^{5}$, welding ${ }^{6,7}$ and also to the corrosion behavior in different media ${ }^{8}$. The effect of different alloying elements has been studied as well ${ }^{9-11}$. However, very few studies are devoted to the application of a surface engineering technique to improve the surface characteristics of the SMSS's ${ }^{12,13}$.
Supermartensitic stainless steels generally suffer from pitting corrosion in chloride containing solutions and pitting potential usually does not exceed $400 \mathrm{mV}$, irrespective the heat treatment ${ }^{14}$ and the type (lean-, medium- or high-alloy) ${ }^{14-16}$. Pitting corrosion is an insidious form of localized corrosion that occurs due to passive layer breakdown in the presence aggressive ions leading to an accelerated underlying metal dissolution $^{17}$.

Application of a surface engineering technique to the SMSS's might improve both corrosion and wear properties extending the application range of this class of steel. Thermochemical treatments that rely on the diffusion of nitrogen and/or carbon, i.e. nitriding, carburising and nitrocarburising, are the most common in industry and usually accomplished by liquid-, gas- or plasma-based processes. The use of such treatments at low temperatures $\left(<550^{\circ} \mathrm{C}\right)$ may lead to the production of the so called expanded phases, which usually applies for $\mathrm{Fe}-\mathrm{Cr}, \mathrm{Co}-\mathrm{Cr}$ and $\mathrm{Ni}-\mathrm{Cr}$ alloys ${ }^{18}$. Transformation of the surface zone into expanded austenite $\left(\gamma_{\mathrm{N}}\right)$ and/or expanded martensite $\left(\alpha_{N}^{\prime}\right)$ depends on the type of material applied and on the treatment conditions ${ }^{19}$, relying on the low mobility of substitutionally dissolved atoms at low temperatures ${ }^{18}$. For the more commonly used austenitic steels expanded austenite 
is obtained ${ }^{18}$ while for martensitic steels a mixture of both expanded phases appears to result ${ }^{20}$.

Expanded austenite and expanded martensite are understood as a super-saturated interstitial solid solutions and the result is a drastic increase in surface hardness and wear resistance of the treated surfaces ${ }^{18,20}$. Furthermore, it has been recognized that corrosion resistance is maintained or even improved as long as the interstitials remain in solid solution ${ }^{18,21}$. To date the effect of thermochemical surface engineering treatments on the electrochemical properties of the SMSS's has not been investigated yet. The present work addresses the influence of plasma nitriding and nitrocarburising on the corrosion behavior of a high-alloy supermartensitic stainless steel.

\section{Experimental}

Squared samples with 20x30x3 mm of the high-alloy SMSS (UNS S41425) in air cooled condition were cut and then prepared by conventional metallographic techniques to obtain a polished surface. Previous heat treating involved soaking the alloy for $1 \mathrm{~h}$ at $940^{\circ} \mathrm{C}$. Standard specification ${ }^{22}$ suggests heat treating the present alloy in the temperature range of $925-980^{\circ} \mathrm{C}$ followed by quenching in air or oil. Subsequent tempering is to be performed at $595^{\circ} \mathrm{C}$. However, in the present study tempering was deliberately not applied since the thermal cycle involved on the thermochemical treatments would lead to simultaneous aging and surface hardening.

The chemical composition of the applied steel was: Fe $-0.014 \mathrm{C}-0.93 \mathrm{Mn}-0.38 \mathrm{Si}-11.96 \mathrm{Cr}-7.00 \mathrm{Ni}-2.05 \mathrm{Mo}-0.045 \mathrm{~N}$ $-0.39 \mathrm{Cu}(\mathrm{wt}-\%)$. Prior to the plasma treatments the samples were cleaned by argon sputtering for $30 \mathrm{~min}$, inside the plasma chamber. Plasma nitriding $(\mathrm{PN})$ and nitrocarburising (PNC) were performed using the DC method with the following gas mixtures: $80 \mathrm{vol} .-\% \mathrm{H}_{2}$ and 20 vol.- $\% \mathrm{~N}_{2}$, for nitriding and 77 vol.- $\% \mathrm{H}_{2}, 20$ vol.- $\% \mathrm{~N}_{2}$ and 3 vol.- $\% \mathrm{CH}_{4}$ for nitrocarburising. The treatments were performed at a working pressure of $500 \mathrm{~Pa}$ for $5 \mathrm{~h}$ at temperatures of 400, 450 and $500^{\circ} \mathrm{C}$. Temperature was monitored with a thermocouple attached to the sample holder.

Optical microscopy was performed on the cross sections of the samples using a Zeiss optical microscope with the interference contrast technique on samples etched with Villela's reagent. The etchant was prepared by dissolving $1 \mathrm{~g}$ of picric acid in a solution of $5 \mathrm{ml}$ of hydrochloric acid and $100 \mathrm{ml}$ of ethanol.

Vickers microhardness measurements were made at the surface of the treated samples using digital Buehler equipment with a load of $50 \mathrm{gf}$ and a dwell time of $10 \mathrm{~s}$. At least six measurements were taken. X-ray diffraction (XRD) patterns were obtained from the surface of the samples applying a Geigerflex Rigaku equipment with a scanning angle from 30 to $80^{\circ}$. The tests were performed using copper radiation $(\mathrm{Cu} \mathrm{K \alpha})$ and continuous scanning with a speed of $2^{\circ} / \mathrm{min}$.
Corrosion tests were performed on treated and untreated specimens in order to comparatively evaluate the electrochemical response of the systems. Experiments were made by means of potentiodynamic polarization tests. The electrochemical cell used to obtain the polarization curves utilized a saturated calomel reference electrode and a platinum auxiliary electrode. The electrolyte employed was an aqueous solution of $\mathrm{NaCl}$ $3.5 \mathrm{wt} . \%$ with a $\mathrm{pH}$ of 6.5 . Prior to the tests the system was led to rest for $10 \mathrm{~min}$. For monitoring the potential and current, an Autolab model PGSTAT - 302 potentiostat was applied. The polarization curves were obtained with a scanning speed of $1 \mathrm{mV} / \mathrm{s}$ from -1.0 to $1.2 \mathrm{~V}$. Each test was repeated twice and a representative curve is shown. For each experiment, $50 \mathrm{ml}$ of the electrolyte was employed and the area exposed to the saline solution was approximately $0.5 \mathrm{~cm}^{2}$.

\section{Results and Interpretation}

\subsection{Metallography and X-ray diffraction}

Figure 1 presents light optical micrographs from the cross sections of plasma nitrided (Fig. 1a-c) and nitrocarburised (Fig. 1d-f) SMSS samples. The base material shows in all treatment conditions the typical lath martensite microstructure. Layers produced at 400 and $450^{\circ} \mathrm{C}$ are white and featureless appearing resistant to the applied etchant. Meanwhile the treatments conducted at $500^{\circ} \mathrm{C}$ yielded dark etched layers that could indicate a loss of the corrosion resistance. Furthermore, cracks that appear parallel to surface are detected on the sample nitrided at $500^{\circ} \mathrm{C}$.

Average thicknesses (e) of the produced layers were directly measured on several optical micrographs taken along the layers and are presented on Table 1 together with surface microhardness $(\mathrm{H})$. Layer thickness increases with temperature and plasma nitriding produces a slightly thicker case when compared to nitrocarburising, for a given temperature. Plasma nitriding also yields slightly larger surface hardness when comparing to nitrocarburising. For both plasma processing methods at least a threefold increase in hardness is observed for all the applied temperatures comparatively to the substrate hardness.

The chemical nature of the compounds produced by plasma nitriding and nitrocarburising of the SMSS was evaluated by X-ray diffraction. Figure 2 depicts the X-ray diffractograms from the surface of the plasma nitrided (Fig. 2a) and nitrocarburised (Fig. 2b) supermartesitic stainless steel. On the bottom of both figures the diffractogram from the untreated SMSS applied as substrate is shown for comparison purposes. Very narrow and strong diffraction lines corresponding to ferrite $(\mathrm{Fe} \alpha)$ are revealed. In fact a small shift to lower Bragg angles is observed for the ferrite peaks which confirms the presence of martensite (see also Fig. 1). Additionally, residual austenite $(\mathrm{Fe} \gamma)$ is detected as well. The weaker austenite peaks indicate the presence of retained austenite after heat treating. 

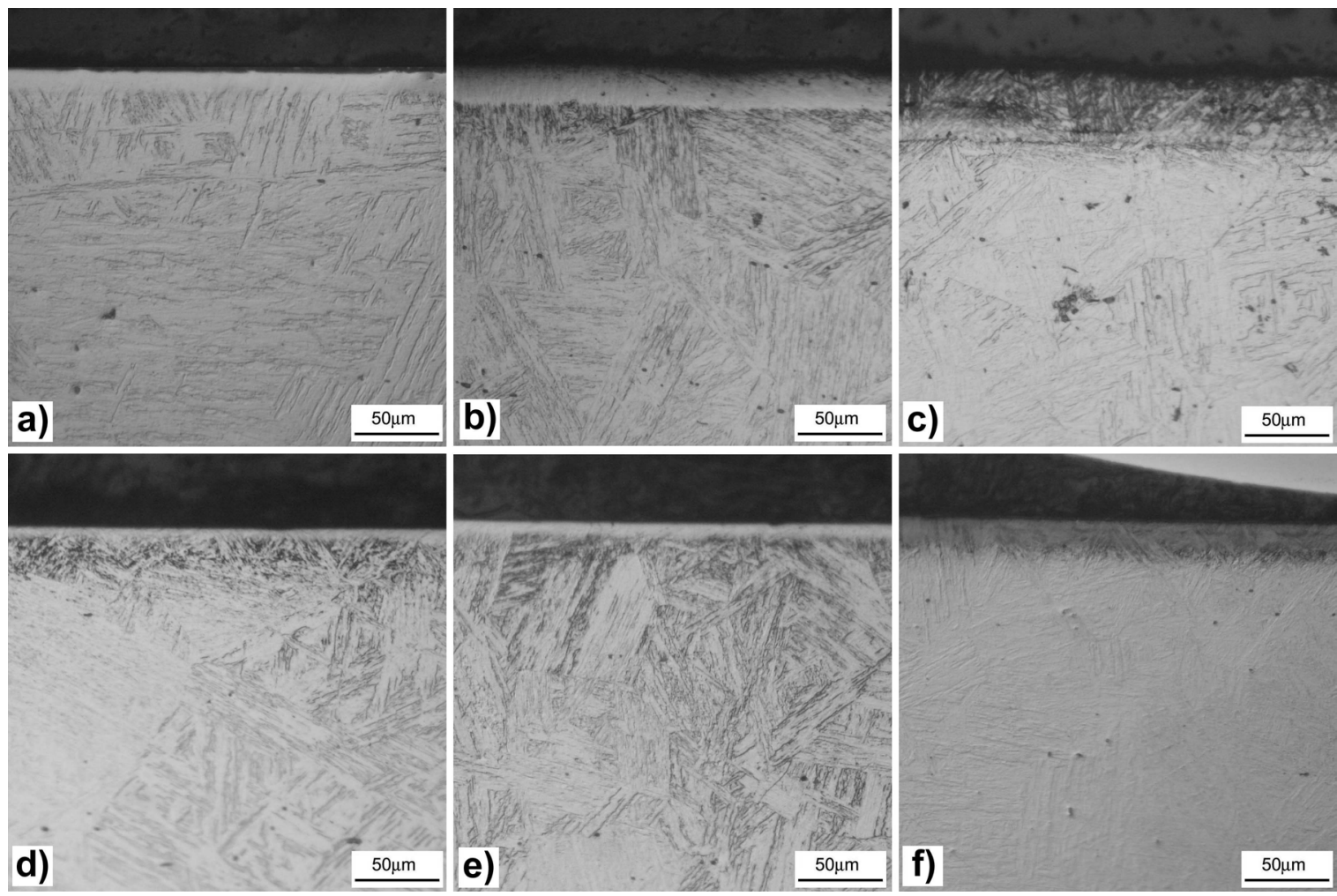

Figure 1. Light optical microscopy of plasma (a-c) nitrided and (d-f) nitrocarburized SMSS samples at (a, d) $400^{\circ} \mathrm{C}$, (b, e) $450^{\circ} \mathrm{C}$ and (c, e) $500^{\circ} \mathrm{C}$ for $5 \mathrm{~h}$
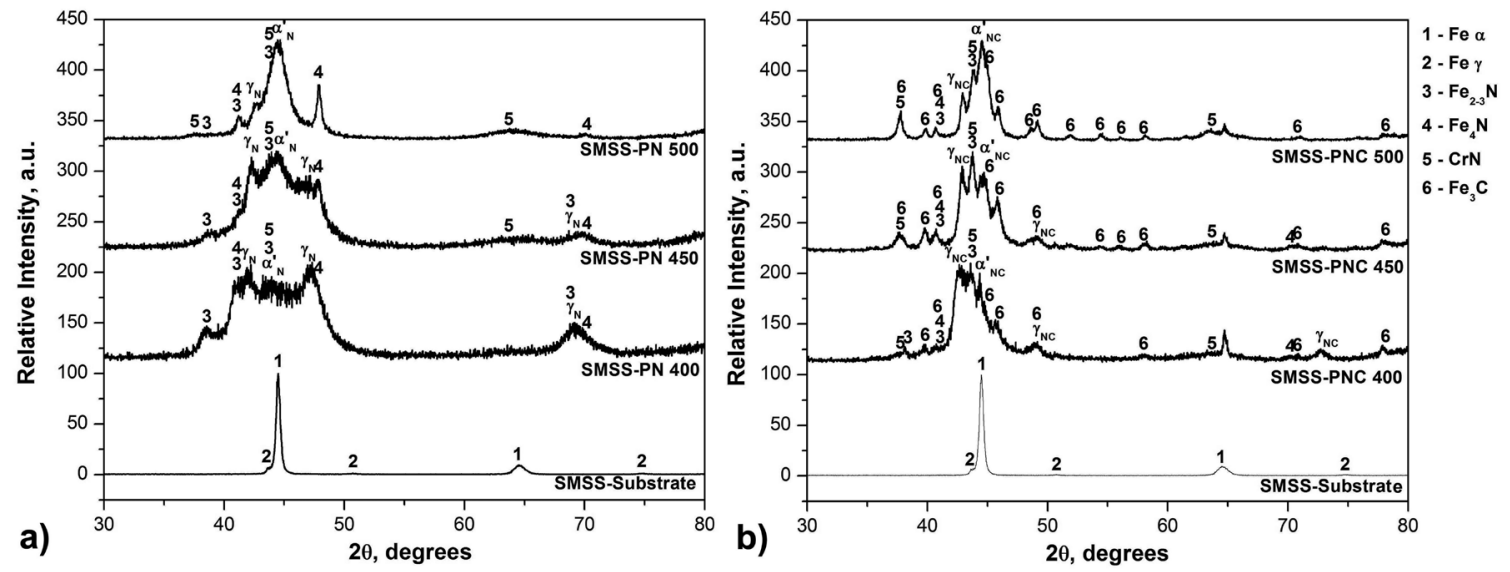

Figure 2. X-ray difraction patterns of plasma (a) nitrided and (b) nitrocaburised SMSS at 400,450 and $500^{\circ} \mathrm{C}$

Table 1. Layer thickness (e) and Vickers surface microhardness (H) of the plasma nitrided and nitrocarburised SMSS samples.

\begin{tabular}{lcc}
\hline Sample & $\mathbf{e , ~} \boldsymbol{\mu m}$ & $\mathbf{H}, \mathbf{H V}$ \\
\hline SMSS-substrate & --- & $436 \pm 4$ \\
PN-400 & $11.6 \pm 0.6$ & $1347 \pm 54$ \\
PN-450 & $21 \pm 1$ & $1390 \pm 37$ \\
PN-500 & $38 \pm 2$ & $1554 \pm 72$ \\
PNC-400 & $8 \pm 1$ & $1273 \pm 34$ \\
PNC-450 & $10 \pm 0.9$ & $1340 \pm 29$ \\
PNC-500 & $27 \pm 1$ & $1475 \pm 39$ \\
\hline
\end{tabular}

For nitriding (Fig. 2a) very broad and overlapped peaks are detected in the $2 \theta$ range from 39 to $49^{\circ}$ and additionally at around $69^{\circ}$. Increasing nitriding temperature appears to develop a more crystalline-like diffraction pattern. Broad diffraction lines at low temperatures is most likely a result of the production of expanded phases such as expanded austenite $\left(\gamma_{N}\right)$ and expanded martensite $\left(\alpha_{N}^{\prime}\right)$. Expanded austenite is possibly generated in two ways, i.e. upon nitriding of retained austenite and converted from martensite due to the austenite-stabilizing character of nitrogen ${ }^{20,23}$. 
Plasma nitriding at $400^{\circ} \mathrm{C}$ for $5 \mathrm{~h}$ undoubtedly produces nitrogen expanded austenite $\left(\gamma_{\mathrm{N}}\right)$ and additional peaks corresponding to the $\varepsilon$-nitride $\left(\mathrm{Fe}_{2-3} \mathrm{~N}\right)$ and expanded martensite $\left(\alpha_{N}^{\prime}\right)$ are seen as well. At $450^{\circ} \mathrm{C}$ the intensity of the reflection lines from $\gamma_{\mathrm{N}}$ and the $\varepsilon$-nitride appear to decrease. Conversely the $\gamma^{\prime}$-nitride $\left(\mathrm{Fe}_{4} \mathrm{~N}\right)$ and chromium nitride $(\mathrm{CrN})$ are nucleated. Nitriding at $500^{\circ} \mathrm{C}$ clearly leads to an increase on the $\gamma^{\prime}$-nitride and chromium nitride peak intensities; indicating that nitriding temperature was too high. Previous literature report that at low plasma treatment temperatures the formation of the $\gamma^{\prime}$-nitride is hindered due to the low diffusivity of nitrogen, favoring the $\varepsilon$-nitride production $^{24,25}$.

Plasma nitrocarburising (Fig. 2b) also yields broad and overlapped diffraction lines suggesting the formation of expanded phases. Upon nitrocarburising at $400^{\circ} \mathrm{C}$ both $\alpha_{\mathrm{NC}}^{\prime}$ and $\gamma_{\mathrm{NC}}$ appear to have been produced together with a minor amount of the $\varepsilon$-nitride. Additionally, the orthorhombic iron carbide $\left(\mathrm{Fe}_{3} \mathrm{C}\right)$, i.e. cementite, is already observed. At $450^{\circ} \mathrm{C}$ the relative intensities of $\gamma_{\mathrm{NC}}$ and the $\varepsilon$-nitride seems to diminish concurrently and more peaks corresponding to cementite emerge. Finally, for nitrcarburising at $500^{\circ} \mathrm{C}$ a possible increase on the amount of cementite and chromium nitride $(\mathrm{CrN})$ is seen indicating again that treatment temperature was too high.

\subsection{Corrosion performance}

The electrochemical response of the layers produced by nitriding and nitrocarburising was studied by potentiodynamic polarization tests and the results are showed in Figure 3. The curves are numbered to help identification of the treatment conditions. The potentiodynamic sweep curve from the untreated SMSS substrate is shown on both graphs for comparison purposes. At negative (cathodic) potentials the curves from the substrate and from nitrided and nitrocarburised samples are very similar, at the three applied treatment temperatures. However distinct behavior occurs at positive (anodic) potentials. Untreated SMSS substrate shows the typical passivating behavior of stainless steels in which the current density sharply increases when the passivation film is effectively broken ${ }^{26}$.

The sample plasma nitrided at $400^{\circ} \mathrm{C}$ (Fig. 3a) yielded the highest corrosion potential and a low current density at the highest applied potential. This specimen does not readily show a passivation behavior, however the observed current density at high applied potentials $(>250 \mathrm{mV})$ is somewhat smaller than the observed for the substrate and for the other treatment temperatures. The specimen nitrided at $450^{\circ} \mathrm{C}$ (Fig. 3a) seems to present an attempt at a passivation though the current density reaches values close to those observed for the substrate. Nitriding at $500^{\circ} \mathrm{C}$ (Fig. 3a) results in a low corrosion potential and no evidence of passivation, i.e. the current density steadily increases.

Plasma nitrocarburising (Fig. 3b) of SMSS has led to no significant increase on the corrosion potential for the three applied treatment temperatures. The specimen nitrocarburised at $400^{\circ} \mathrm{C}$ (Fig. 3b) shows an attempt at a passivation; nevertheless, the current density steadily rises. Samples nitrocarburised at 450 and $500^{\circ} \mathrm{C}$ both yielded an abrupt increase in current density, most likely indicating that these layers do not offer protection when immersed in 3.5\% $\mathrm{NaCl}$ solution. In fact the samples nitrocarburised at 450 and $500^{\circ} \mathrm{C}$ appear to possess lower protection than the base steel.

After examining the polarization curves in Fig. 3 the electrochemical parameters from plasma nitrided and nitrocarburised SMSS were collected and are presented in Table 2. The corrosion potential $\left(\mathrm{E}_{\text {corr }}\right)$, corrosion current density $\left(\mathrm{I}_{\text {corr }}\right)$ and current density at the highest applied potential $\left(\mathrm{I}_{\mathrm{E}=1.2 \mathrm{~V}}\right)$ give indications on the corrosion resistance of the studied specimens.

It is clear from Tab. 2 that corrosion potential becomes more negative at highertreatment temperatures. Similarly, the current density at the highest applied potential appears to increase with temperature. Furthermore, the corrosion
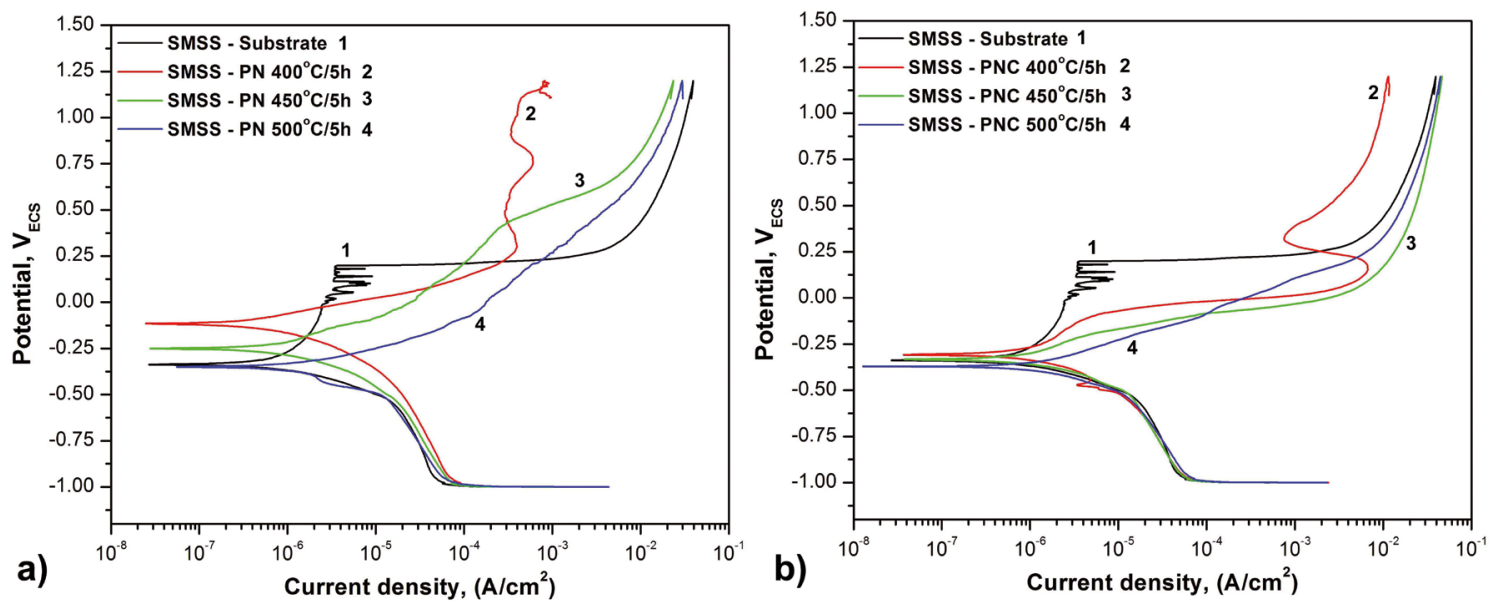

Figure 3. Potentiodynamic polarization curves of plasma (a) nitrided and (b) nitrocarburised SMSS samples in $3.5 \% \mathrm{NaCl}$ solution 
Table 2. Electrochemical parameters from the polarization curves of the plasma nitrided and nitrocarburised SMSS samples.

\begin{tabular}{lccc}
\hline Sample & $\begin{array}{c}\mathbf{E}_{\text {corr }} \\
\mathbf{m V}\end{array}$ & $\begin{array}{c}\mathbf{I}_{\text {corr }} \\
\mathbf{1 0}^{-8} \mathbf{x A} / \mathbf{c m}^{2}\end{array}$ & $\begin{array}{c}\mathbf{I}_{\mathbf{E}=\mathbf{1 . 2}}, \\
\mathbf{1 0}^{-3} \mathbf{x} \mathbf{A} / \mathbf{c m}^{2}\end{array}$ \\
\hline SMSS-substrate & -338 & 2.7 & 39.4 \\
PN-400 & -115 & 2.5 & 0.8 \\
PN-450 & -249 & 2.8 & 23.6 \\
PN-500 & -350 & 5.6 & 29.7 \\
PNC-400 & -307 & 3.7 & 11.4 \\
PNC-450 & -331 & 3.8 & 46.4 \\
PNC-500 & -371 & 1.3 & 44.5 \\
\hline
\end{tabular}

current for nitrided specimens increase with temperature. These observations indicate a possible loss of corrosion resistance for the treatments conducted at higher temperatures (e.g. $500^{\circ} \mathrm{C}$ ).

Like previously stated based on Fig. 3, plasma nitriding at $400^{\circ} \mathrm{C}$ yields a more positive corrosion potential and a low current density during the tests (see Fig. 3 and Tab. 2). Furthermore, the surfaces of the samples submitted to polarization in $\mathrm{NaCl}$ solution were examined by optical microscopy to infer on the dominating corrosion mechanism. Micrographs are presented on Figures 4, 5 and 6, for the SMSS substrate, plasma nitrided and nitrocarburised samples, respectively.

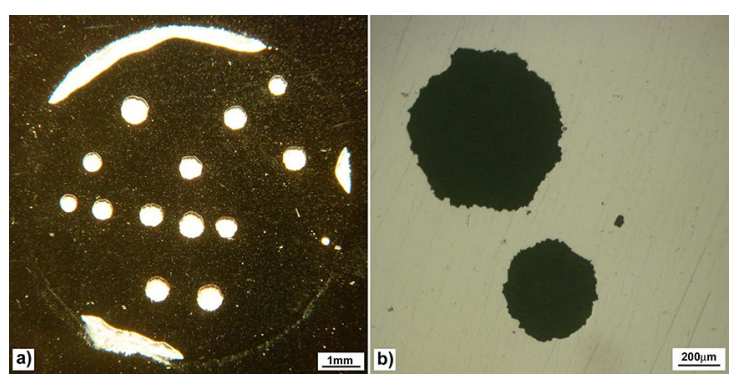

Figure 4. Optical micrographs from the corroded region on the untreated SMSS substrate highlighting: (a) the whole area and (b) corrosion pits at 50x of magnification

Figure 4 shows optical micrographs from the corroded surface of the air cooled SMSS substrate. In Fig. 4a the whole area exposed to the electrolyte is seen showing crevice corrosion and wide pits. Few circular pits are detected, albeit its size may reach $650 \mu \mathrm{m}$ as seen in Fig. $4 \mathrm{~b}$. The analysis of Fig. 4 confirms the reasoning of localized corrosion occurrence based on Fig. 3. Such localized corrosion morphology is typical of stainless steels that form a passivation film.

Figure 5 exhibits photomicrographs from the surface of the SMSS specimens plasma nitrided at $400^{\circ} \mathrm{C}(\mathrm{a}, \mathrm{d}), 450^{\circ} \mathrm{C}$ (b, e) and $500^{\circ} \mathrm{C} \mathrm{(c,} \mathrm{f),} \mathrm{after} \mathrm{polarization} \mathrm{in} 3.5 \% \mathrm{NaCl}$. Surface inspection of the sample nitrided at $400^{\circ} \mathrm{C}$ indicates that pitting corrosion did not occur. At high magnification (Fig. 5d) the surface appears free of pits exhibiting the martensitic microstructure. The specimen nitrided at $450^{\circ} \mathrm{C}$ shows the presence of sparse areas of localized corrosion, after polarization, which can only be clearly detected at higher magnification (Fig. 5e). Nitriding at $500^{\circ} \mathrm{C}$ undergoes to a severe pitting during polarization. Wide pits are detected even at lower magnification optical imaging (Fig. 5c). From the micrographs of the plasma nitrided surfaces it is clear that occurrence of localized corrosion, i.e. pitting, intensifies as treatment temperature is increased to $500^{\circ} \mathrm{C}$.

Figure 6 displays photomicrographs from the surface of the SMSS specimens plasma nitrocarburised at $400^{\circ} \mathrm{C}$ (a, d), $450^{\circ} \mathrm{C}(\mathrm{b}, \mathrm{e})$ and $500^{\circ} \mathrm{C}(\mathrm{c}, \mathrm{f})$, after polarization in $3.5 \% \mathrm{NaCl}$. Nitrocarburising at $400^{\circ} \mathrm{C}$ yielded sparse corrosion pits spread on the area exposed to the electrolyte and the remaining exposed area appears to have suffered a uniform dissolution. Meanwhile the layer nitrocarburised at $450^{\circ} \mathrm{C}$ shows an intense dissolution associated with pitting corrosion, after polarization. Such combined process seems to have entirely corroded the thermochemically produced layer (see Fig. 6b). The layer produced at $500^{\circ} \mathrm{C}$ yields a severe pitting associated with a uniform dissolution after polarization, although the layer was not entirely corroded.

Pitting corrosion is a recurrent problem in different classes of stainless steels applied in several industrial sectors. This scenario calls for a special attention to the phenomena since it may lead to premature failures. Figures 5 and 6 indicate that localized corrosion also occurs in thermochemically treated surfaces. The present results indicate that thermochemical surface alloying with nitrogen and/or carbon is a viable alternative to prevent localized corrosion of SMSS's provided that treatment conditions, i.e. atmosphere, temperature and duration, are well selected.

\section{Discussion}

The SMSS's are a result of a balanced chemical composition that aims at maintaining the room temperature martensitic microstructure, adequate corrosion resistance and weldability ${ }^{1}$. Typical pitting potential of such steels, in chloride containing solutions, is in the range of $200-400 \mathrm{mV}^{14,15}$. The present steel (UNS S41425) indeed shows pitting potential in the abovementioned range indicating that heat treatment was correctly applied. In fact the protective film rupture process begins in a early potential (see Fig. 3) and is effectively finished at around $250 \mathrm{mV}$ when the current density rises abruptly. After the application of a thermochemical treatment at the surface of the SMSS its composition and corrosion properties are significantly altered.

X-ray diffraction analysis applied on the substrate shows that untreated base alloy is composed of martensite and retained austenite. For nitrided and nitrocarburised layers distinct compounds result, depending on the treatment condition. Low temperature surface engineering with nitrogen and/or carbon usually develop a composition profile in which the 


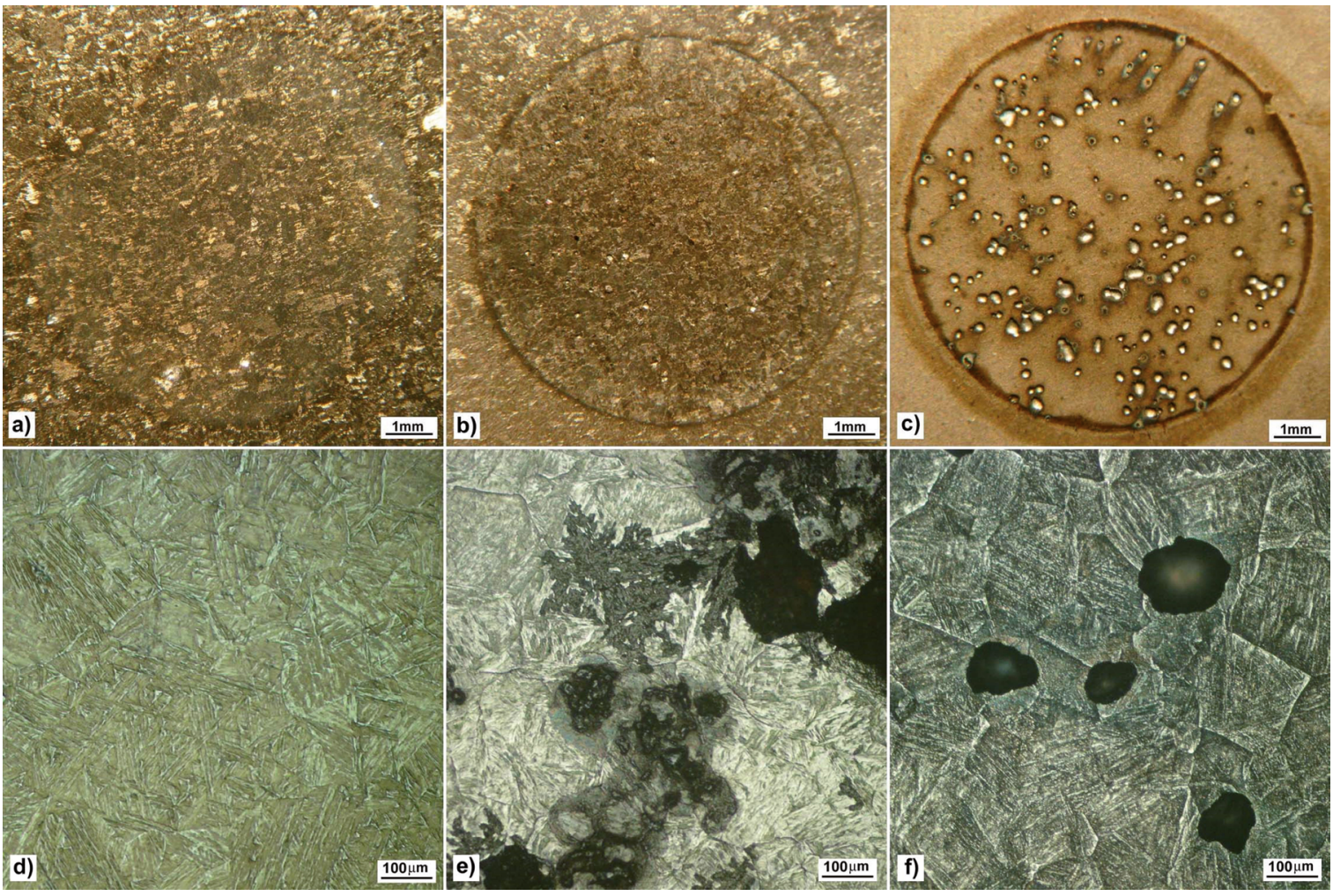

Figure 5. Light optical micrographs from the corroded region of plasma nitrided SMSS at (a, d) $400{ }^{\circ} \mathrm{C}$, (b, e) $450^{\circ} \mathrm{C}$ and $(\mathrm{c}, \mathrm{f}) 500^{\circ} \mathrm{C}$ after potentiodynamic polarization in $3.5 \% \mathrm{NaCl}$ solution
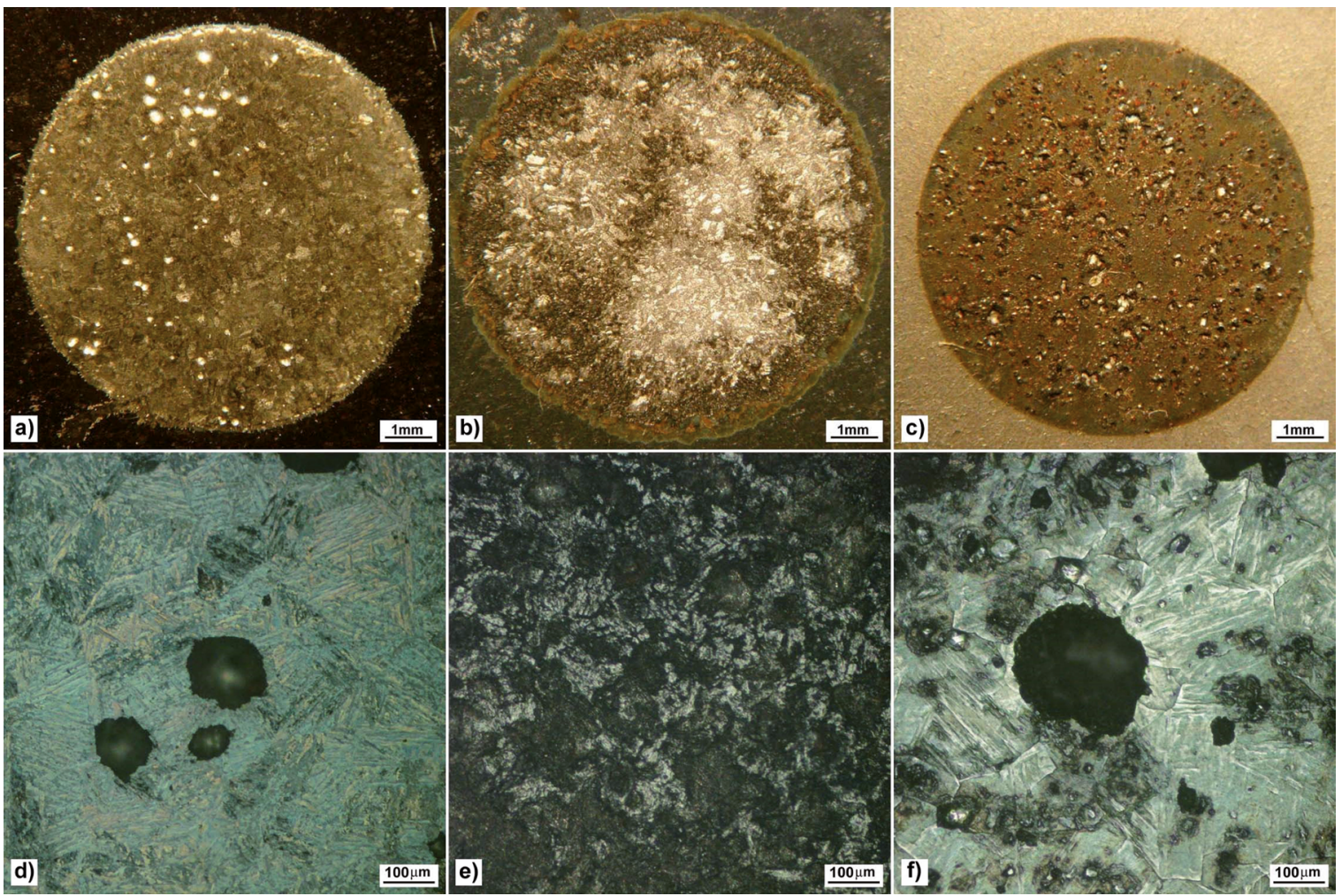

Figure 6. Light optical micrographs from the corroded region of plasma nitrocarburised SMSS at (a, d) $400^{\circ} \mathrm{C},(\mathrm{b}, \mathrm{e}) 450^{\circ} \mathrm{C}$ and $(\mathrm{c}, \mathrm{f})$ $500^{\circ} \mathrm{C}$ after potentiodynamic polarization in $3.5 \% \mathrm{NaCl}$ solution 
interstitial content is high at the surface and decreases towards the core ${ }^{27}$. Such gradient allows an in-depth development of distinct phases. Therefore it is believed that iron and chromium nitrides and/or iron carbides develop at the surface of the SMSS, followed by the expanded phases beneath.

As indicated by the X-ray diffractograms (Fig. 2) very broad and overlapped diffraction lines result for both nitriding and nitrocarburising at $400^{\circ} \mathrm{C}$. Increasing temperature leads to more crystalline-like patterns. For both thermochemical treatments the amount of $\varepsilon$-nitride and expanded phases seems to decrease with temperature. Conversely, the $\gamma^{\prime}$-nitride and chromium nitride $(\mathrm{CrN})$ fractions appear to increase with temperature. For nitrocarburising cementite is observed even at the lowest treatment temperature, i.e. $400^{\circ} \mathrm{C}$, and its peak intensities appear to increase with temperature as well.

The tremendous increase in surface hardness (see Tab. 1) for both treatments is most likely associated to the development of more nitrides/carbides at higher treatment temperatures. At higher temperatures the metallic atoms ( $\mathrm{Cr}$ and $\mathrm{Fe}$, for example) acquire some mobility therefore yielding the appearance of suchnitrides/carbides.

On the other hand it has been previously shown that the development of more chromium nitride $(\mathrm{CrN})$ at the surface of thermochemically treated stainless steels appears to undermine the corrosion resistance ${ }^{28}$. Li and Bell, 2004 performed plasma nitriding of an AISI 316 austenitic steel and suggested that once $\mathrm{CrN}$ forms chromium is depleted in the matrix which prevents the formation of a dense and continuous oxide layer at the surface ${ }^{28}$. Plasma nitriding of a superaustenitic stainless steel revealed similar results ${ }^{21}$. However, in another study involving plasma nitriding of the AISI 410, Li and Bell, 2006 observed that the formation of $\mathrm{CrN}$ was of less importance in affecting the corrosion resistance of the steel ${ }^{29}$. Therefore it appears that the presence of $\mathrm{CrN}$ is more deleterious to the corrosion performance of nitrided austenitic stainless steels than to the martensitic stainless steels. To date, there is a lack of studies in the technical literature concerning the effect of thermochemical treatments on the electrochemical properties of SMSS's. Most of the corrosion related work concentrates in studying the performance of SMSS weldments ${ }^{6,7}$ and the influence of alloying additions ${ }^{9-11}$, for example.

In the present work the corrosion resistance of plasma nitrided SMSS is most likely associated to the precipitation of $\mathrm{CrN}$. The higher the nitriding temperature, the more $\mathrm{CrN}$ is observed, and thus the corrosion performance is damaged. Additionally, optical micrographs indicate that the severity of pitting corrosion increases with temperature (see Fig. 5).

For nitrocarburising of SMSS the presence of cementite $\left(\mathrm{Fe}_{3} \mathrm{C}\right)$, for the three applied temperatures, appears to have played a crucial role in undermining the corrosion resistance (see Fig. 3b). No clear sign of passivation is seen for all treatment temperatures. In a study by Li and Bell, 2007, a comparison of the electrochemical behavior of plasma nitrided, carburised and nitrocarburised AISI 410 martensitic stainless steel, at $450^{\circ} \mathrm{C}$ for $20 \mathrm{~h}$, is given ${ }^{30}$. The authors found that plasma nitriding yields a significant improvement on the corrosion resistance of the steel and plain carburising (which produced mainly cementite at the surface of the steel) results in a similar polarization curve as the untreated alloy. Meanwhile, nitrocarburising leads to an intermediate behavior ${ }^{30}$. Based on the present research and previous results ${ }^{30}$ it is reasonable to claim that the presence of cementite appears to be responsible for the poor corrosion properties of plasma nitrocarburised SMSS. Furthermore, microscopic examination of the corroded surfaces indicates that corrosion damage intensifies when the nitrocarburising temperature is increased (see Fig. 6). Thus, for nitrocarburising a more careful selection of the treatment parameters should be carried out when aiming to improve the corrosion resistance.

For an improved corrosion resistance it is believed that a homogeneous single-phase layer is more attractive ${ }^{31}$. In a multi-phase layer with increased interfacial area corrosion behavior could be impaired due to the formation of galvanic microcells between the microstructural phases ${ }^{32}$. This could be the case when different nitrides and/or carbides are produced at the surface.

Besides the electrochemical behavior, previous studies have demonstrated that plasma surface engineering of supermartensitic stainless steels improve its wear performance ${ }^{12,13}$. Fernandes et al., 2012, found that wear resistance of the UNS S41425 SMSS increases with the processing temperature for both nitriding and nitrocarburising ${ }^{12}$. Therefore, for optimum wear and corrosion performances a careful selection of the type of treatment and working temperature must be carried out.

\section{Conclusion}

Based on the experimental results and discussion, the following conclusions can be drawn:

- The microstructure and characteristics of plasma nitrided and nitrocarburised SMSS samples are strongly affected by the treatment type and temperature;

- Surface hardness increases with temperature for both nitriding and nitrocarburising treatments;

- Different phases are observed depending on the temperature. The amount of $\varepsilon$-nitride and expanded phases seems to decrease with temperature for both treatments. Conversely, the $\gamma^{\prime}$-nitride and chromium nitride $(\mathrm{CrN})$ fractions appear to increase with temperature. Cementite is observed even at the lowest nitrocarburising treatment temperature; 
- Nitriding at $400^{\circ} \mathrm{C}$ was the only condition in which significant improvement of corrosion is observed. For plasma nitriding and nitrocarburising at 450 and $500^{\circ} \mathrm{C}$ pitting corrosion was detected and the severity of pitting appears to increase with temperature. Low temperature plasma nitriding appears to be a more adequate treatment to improve the corrosion resistance of the SMSS's.

\section{Acknowledgements}

The authors are grateful for the Brazilian funding agencies CAPES and CNPq.

\section{References}

1. van der Winden H, Toussaint P, Coudreuse L. Past, present and future of weldable supermartensitic alloys. In: Proceedings of Second International Conference of Supermartensitic Stainless Steels; 2002 Oct 3-4; Brussels, Belgium . p. 9-13.

2. Zou DN, Han Y, Zhang W, Fang XD. Influence of Tempering on Mechanical Properties of 00Cr13Ni4Mo Supermartensitic Stainless Steel. Journal of Iron and Steel Research International. 2010;17(8):50-54

3. Carrouge D, Bhadeshia HKDH, Woollin P. Effect of d-ferrite on impact properties of supermartensitic stainless steel heat affected zones. Science and Technology of Welding and Joining. 2004;9(5):377-389.

4. Qin B, Wang ZY, Sun QS. Effect of tempering temperature on properties of $00 \mathrm{Cr} 16 \mathrm{Ni} 5 \mathrm{Mo}$ stainless steel. Materials Characterization. 2008;59(8):1096-1100.

5. da Silva GF, Tavares SSM, Pardal JM, Silva MR, de Abreu HFG. Influence of heat treatments on toughness and sensitization of a Ti-alloyed supermartensitic stainless steel. Journal of Materials Science. 2011;46:7737-7744.

6. Pereda MD, Gervasi CA, Llorente CL, Bilmes PD. Microelectrochemical corrosion study of super martensitic welds in chloride-containing media. Corrosion Science. 2011;53(12):3934-3941.

7. Della Rovere CA, Aquino JM, Ribeiro CR, Silva R, Alcântara NG, Kuri SE. Corrosion behavior of radial friction welded supermartensitic stainless steel pipes. Materials \& Design (1980-2015).2015;65:318-327.

8. Anselmo N, Maya JE, Mariano NA, Nascente PAP, Kuri SE. Corrosion behavior of supermartensitic stainless steel in aerated and $\mathrm{CO}_{2}$-saturated synthetic seawater. Materials Science and Engineering: A. 2006;428(1-2):73-79.

9. Rodrigues CAD, Bandeira RM, Duarte BB, Tremiliosi-Filho G, Jorge AM Jr. Effect of phosphorus content on the mechanical, microstructure and corrosion properties of supermartensitic stainless steel. Materials Science and Engineering: A . 2016;650:75-83.

10. Ma X, Wang L, Subramanian SV, Liu C. Studies on Nb Microalloying of $13 \mathrm{Cr}$ Super Martensitic Stainless Steel. Metallurgical and Materials Transactions A. 2012;43(12):44754486.
11. Lian Y, Huang J, Zhang J, Zhang C, Gao W, Zhao C. Effect of 0.2 and $0.5 \%$ Ti on the microstructure and mechanical properties of $13 \mathrm{Cr}$ supermartensitic stainless steel. Journal of Materials Engineering and Performance. 2015;24(11):4253-4259.

12. Fernandes FAP, Totten GE, Gallego J, Casteletti LC. Plasma nitriding and nitrocarburising of a supermartensitic stainless steel. International Heat Treatment and Surface Engineering. 2012;6(1):24-27.

13. Kurelo BCES, de Souza GB, da Silva SLR, Serbena FC, Foerster $\mathrm{CE}$, Alves C Jr. Plasma nitriding of $\mathrm{HP} 13 \mathrm{Cr}$ supermartensitic stainless steel. Applied Surface Science. 2015;349:403-414.

14. Bilmes PD, Llorente CL, Méndez CM, Gervasi CA. Microstructure, heat treatment and pitting corrosion of $13 \mathrm{CrNiMo}$ plate and weld metals. Corrosion Science. 2009;51(4):876-881.

15. Mesquita TJ, Chauveau E, Mantel M, Bouvier N, Koschel D. Corrosion and metallurgical investigation of two supermartensitic stainless steels for oil and gas environments. Corrosion Science. 2014;81:152-161.

16. Farrar JCM, ed. The Alloy Tree: A Guide to Low-Alloy Steels, Stainless Steels and Nickel-Base Alloys. Cambridge: Woodhead Publishing; 2004.

17. Frankel GS. Pitting corrosion of metals - A review of the critical factors. Journal of the Electrochemical Society. 1998;145(6):21862198.

18. Dong H. S-phase surface engineering of $\mathrm{Fe}-\mathrm{Cr}, \mathrm{Co}-\mathrm{Cr}$ and NiCr alloys. International Materials Reviews. 2010;55(2):65-98.

19. Borgioli F, Galvanetto E, Bacci T. Low temperature nitriding of AISI 300 and 200 series austenitic stainless steels. Vacuum. 2016;127:51-60.

20. Frandsen RB, Christiansen T, Somers MAJ. Simultaneous surface engineering and bulk hardening of precipitation hardening stainless steel. Surface and Coatings Technology. 2006;200(16-17):5160-5169.

21. Fernandes FAP, Heck SC, Pereira RG, Picon CA, Nascente PAP, Casteletti LC. Ion nitriding of a superaustenitic stainless steel: Wear and corrosion characterization. Surface and Coatings Technology. 2010;204(18-19):3087-3090.

22. ASTM International. ASTM A565 - Standard Specification for Martensitic Stainless Steel Bars for High-Temperature Service. West Conshohocken: ASTM International; 2017.

23. Dong H, Esfandiari M, Li XY. On the microstructure and phase identification of plasma nitrided $17-4 \mathrm{PH}$ precipitation hardening stainless steel. Surface and Coatings Technology. 2008;202(13):2969-2975.

24. Basso RLO, Pastore HO, Schmidt V, Baumvol IJR, Abarca SAC, de Souza FS, et al. Microstructure and corrosion behaviour of pulsed plasma-nitrided AISI H13 tool steel. Corrosion Science. 2010;52(9):3133-3139.

25. Ochoa EA, Figueroa CA. Influence of the microstructure on steel hardening in pulsed plasma nitriding. Journal of Vacuum Science \& Technology A. 2008;26(3):328-332.

26. Tian W, Du N, Li S, Chen S, Wu Q. Metastable pitting corrosion of 304 stainless steel in $3.5 \% \mathrm{NaCl}$ solution. Corrosion Science. 2014;85:372-379. 
27. Christiansen T, Somers MAJ. Low temperature gaseous surface hardening of stainless steel: the current status. International Journal of Materials Research. 2009;100(10):1361-1377.

28. Li CX, Bell T. Corrosion properties of active screen plasma nitrided 316 austenitic stainless steel. Corrosion Science. 2004;46(6):1527-1547.

29. Li CX, Bell T. Corrosion properties of plasma nitrided AISI 410 martensitic stainless steel in $3.5 \% \mathrm{NaCl}$ and $1 \% \mathrm{HCl}$ aqueous solutions. Corrosion Science. 2006;48(8):2036-2049.
30. Li CX, Bell T. A comparative study of low temperature plasma nitriding, carburising and nitrocarburising of AISI 410 martensitic stainless steel. Materials Science and Technology. 2007;23(3):355-361.

31. Weber T, de Wit L, Saris FW, Königer A, Rauschenbach B, Wolff GK, et al. Hardness and corrosion resistance of single-phase nitride and carbide on iron. Materials Science and Engineering: A.1995;199(2):205-210.

32. Perez N, ed. Electrochemistry and Corrosion Science. $2^{\text {nd }}$ ed. London: Springer Nature; 2016. 